\title{
JBook TReviews.
}

Vom irdischem Gut. Vier biblischen Ansprachen uber Luke I2:13-34. VON Dr. Bernhard Weiss. Pp. 45.

These four expository sermons, which are well worth reading as sermons, contain an uncommon explanation of the parable of the rich fool. Most find in this parable nothing more than a powerful presentation "in concrete lively form " of "a moral commonplace." Dr. Weiss thinks that we must go deeper. The context shows that our Lord has just to all intents and purposes been offered the Messianic crown. He had been applied to as the highest authority in Israel, and had refused to entertain the application, because he could not be judge and arbiter until he had become Saviour and Redeemer. When he proceeded to utter this parable, the thought of his poor people was still in his mind. "He knew only too well how this people on which had been bestowed the best of blessings, that many prophets and kings had desired to see and had not seen,- - this people which hoped that it had found in him the goal of its wishes, was moving toward a more terrible disappointment than the farmer experienced in the night of his decease, because it strove only to collect earthly treasures and not to be rich toward God." This striking exposition, which need not exclude that usually adopted, deserves careful consideration.

W. TAYLOR SMITH.

The Earliest Life of Christ ever compiled from the four Gospels, being The Diatessaron of Tatian, literally translated from the Arabic Version and containing the Four Gospels woven into one story; with an historical and critical introduction, notes, and appendix. By the Rev. J. HAMLYN HILL, B.D. Edinburgh: T. \& T. Clark, I 894. Imported by Charles Scribner's Sons. Chicago: A. C. McClurg \& Company. 8vo, pages $8+379$. Price, $\$ 4.20$.

It is a pleasure to call attention to this book, which puts before the English reader an ancient work whose discovery in very recent times-or to speak more exactly, whose publication, since the existence of the manuscript in the Vatican Library had been known since I 7 I9-has been regarded by scholars as one of the highest importance in its bearing on the criticism of the gospels.

In his article on Tatian in the Smith \& Wace Dictionary of Christian Biography, Professor Fuller begins the section on the Diatessaron with the sentence, "The history of the recovery of this work is sufficiently romantic." But when that sentence was written the Diatessaron itself had not been published, and the most interesting chapter of the romantic history was, in a sense, still to be written. From the days of Victor, Bishop of Capua, who died A. D. 554, until 